\title{
Production Performance and Egg Quality of Laying Hens as Influenced by Genotype and Rearing System
}

\section{-Author(s)}

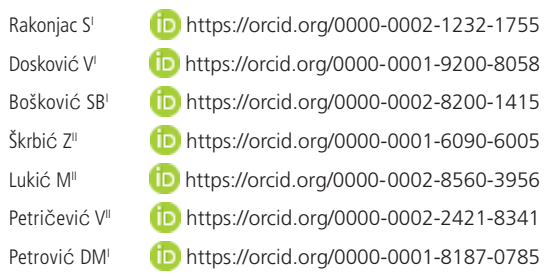

University of Kragujevac, Faculty of Agronomy in Čacak, Cara Dušana 34, 32000 Čačak, Serbia.

Institute of Animal Husbandry, Belgrade-Zemun Autoput 16, 11080 Zemun, Serbia.

\section{-Mail Address}

Corresponding author e-mail address Simeon Rakonjac

University of Kragujevac, Faculty of Agronomy in Čačak - Cara Dušana 34, 32000 Čačak Čačak 32000 - Serbia.

Phone: +38132303400

Email: simcepb@yahoo.com

\section{aKeywords}

Egg quality, genotype, laying hens, rearing systems.

\section{ABSTRACT}

The aim of this study was to evaluate the effect of rearing systems and genotypes on production performance and egg quality. Isa Brown and New Hampshire genotypes were used in this study. These two genotypes were housed in floor and organic rearing systems. During the experimental period, which lasted one year (52 weeks), the following production performance parameters were recorded: egg production, daily egg mass, feed consumption, feed conversion efficiency, and mortality. Fifteen eggs per group were collected for analysis at 64 weeks of hen age. These samples were evaluated for external parameters (egg weight and egg shape index), internal parameters (albumen height, Haugh unit, and the proportions of albumen, yolk and shell), eggshell quality parameters (shell thickness, shell deformation and shell breaking strength), and eggs' chemical composition (dry matter, minerals, protein and lipids). Generally, Isa Brown hens had better production performance than New Hampshire hens. At the same time, organic New Hampshire layers performed better than floor-reared ones. Genotype had a significant effect on all ten egg quality parameters (external, internal and eggshell quality), rearing system independently affected only egg weight, and the interaction of the observed factors significantly influenced seven parameters. Genotype had a significant effect on three of the four chemical composition parameters, while no significant effect of the rearing system was established on the chemical composition of eggs. The rearing system $x$ genotype interaction significantly affected the eggs' protein content.

\section{INTRODUCTION}

Organic eggs' purchase and consumption have become particularly popular among consumers who believe that organically produced eggs are of better quality (Sokołowicz et al., 2019). This stems from the perception that products obtained from "happy animals" are better and healthier for human consumption. Food produced in this way also has a functional role - not only in reducing hunger and providing basic nutrients for human consumption, but also in preventing the occurrence of diseases associated with inadequate nutrition, as well as improving the physical and mental well-being of the consumer (Siró et al., 2008). Egg components can have antimicrobial, immunomodulatory, antioxidant, anticancer, and antihypersensitivity effects on human health (Abeyrathne et al., 2013). It is important to note that the cheapest way, with the least environmental impact, of covering the human body's daily need for animal protein is with eggs (Molnár \& Szollosi, 2020). For that reason, alternative rearing systems for laying hens have greatly expanded, especially in EU countries. The Committee for the Common Organisation of the Agricultural Markets (2021) reported that $18 \%$ of 
hens in EU countries have outdoor access (free range and organic taken together).

Hybrids or native breeds can be used for rearing in alternative production systems (Sokołowicz et al., 2018b). Since most hybrids are selected for intensive production, it is not entirely clear whether they can be successfully used in alternative rearing systems, especially organic ones. Namely, these birds require high levels of energy, vitamins, proteins, and especially some limiting amino acids. These needs often cannot be satisfied only through natural nutrients, i.e. without the addition of synthetic sources of these substances, the use of which is forbidden in organic production. (Rakonjac et al., 2019). The mortality of hybrids reared outdoors is also often significantly higher than the established standards. For this reason, indigenous breeds are usually recommended for organic poultry production because they are easily adapted to prevailing local environments and make efficient use of paddocks (Sokołowicz et al., 2019). However, the main obstacle to the use of these breeds for egg production is their poorer production performance as compared to hybrids, leading to poorer economic results.

Therefore, this study aimed at evaluating the effect of rearing systems and genotypes on production performance and egg quality.

\section{MATERIAL AND METHODS}

The experiment was arranged in a $2 \times 2$ factorial design with two layer genotypes and two rearing systems (30 birds per group). Isa Brown hybrid and dual-purpose New Hampshire breed were used in this study. These two genotypes were housed in floor and organic rearing systems when hens were 18 weeks of age.

In both rearing systems, stocking density was 2.5 birds $/ \mathrm{m}^{2}$. Organic layers also had about $5 \mathrm{~m}^{2}$ per bird of available outdoor area covered with grass and bushes, which enabled them to supplement their diets using vegetation and small creatures living outdoors.

Floor-reared laying hens were fed a standard commercial diet ad libitum, the average chemical composition of which is shown in Table 1. In the organic system, feeders and drinkers were located both indoor and outdoor. It is important to note that diet for organic hens was complete, without synthetic amino acids, vitamins and minerals, with more than $80 \%$ of organic components. Its chemical composition is also shown in Table 1. Water was available ad libitum in all experimental groups.
Table 1 - Chemical composition of laying hens' diet.

\begin{tabular}{lcc}
\hline & Floor system & Organic system \\
\hline Chemical composition & $\%$ & $\%$ \\
Dry matter & 88.38 & 89.82 \\
Crude proteins & 16.79 & 16.82 \\
Crude fats & 5.15 & 4.31 \\
Cellulose & 4.82 & 4.29 \\
Ash & 12.52 & 12.68 \\
Ca & 3.72 & 3.43 \\
Total P & 0.71 & 0.81 \\
Na & 0.17 & 0.18 \\
Lysine & 0.79 & 0.80 \\
Methionine+cystine & 0.68 & 0.48 \\
Metabolisable energy. MJ & $11.5 \mathrm{MJ}$ & $11.3 \mathrm{MJ}$ \\
\hline
\end{tabular}

Production performance parameters (including egg production, daily egg mass, feed consumption, feed conversion efficiency, and mortality) were recorded throughout the experimental period, which lasted one year (52 weeks), fifteen eggs per group were collected for analysis at 64 weeks of hen age. These samples (eggs were one day old) were evaluated for external, internal and eggshell quality parameters and the basic chemical composition of eggs was analyzed.

- Egg weight was measured on an electronic scale with an accuracy of $10^{-2} \mathrm{~g}$.

- Egg shape index, or short-axis to long-axis length ratio (\%), was determined using a special device (B.V. Apparatenfabriek van Doorn, Holland).

- Albumen, yolk, and shell weights were measured on an electronic scale with an accuracy of $10^{-2} \mathrm{~g}$, and then their proportions were calculated in relation to the whole egg weight.

- Albumen height was determined by a tripod micrometer (AMES, USA)

- Haugh units were calculated according to the following formula:

$H U=100 \log \left(H+7.57-1.7 M^{0.37}\right)$

where $\mathrm{H}=$ albumen height, $\mathrm{mm}$. $\mathrm{M}=$ egg weight, $\mathrm{g}$.

- Shell deformation was measured using a special device (Marius, Holland).

- Shell strength was tested with an Egg Crusher made by Pavlovski \& Vitorović (1996)

- Shell thickness was measured on shell fragments sampled from the equatorial circumference (SOMET, USA)

The analysis of the chemical composition of eggs was performed based on AOAC procedures (AOAC, 1990).

Production performance data were analysed by the non-parametric Wilcoxon test. Egg quality data were analysed by ANOVA and LSD test (Stat Soft Inc Statistica for Windows. Version 7.0., 2006). 


\section{RESULTS AND DISCUSSION} 2.

Egg production parameters are presented in Table

As expected, dual-purpose New Hampshire hens achieved lower values for egg production, daily egg mass and feed conversion efficiency $(p \leq 0.05)$ as compared to Isa Brown hybrid because of their genetic origin that brings together meat characteristics to egg laying capability. Rizzi \& Chiericato (2005) also recorded significantly higher egg production for hybrids in the organic production system (Hy-Line Brown - 94.1\%, Hy-Line White - $88.7 \%$ ) as compared to two Italian breeds (Robusta Maculata - 63\%, Ermellinata of Rovigo - 56.8\%) in 32-week old hens. Similarly to the results of this study, Mostert et al. (1995) reported that the New Hampshire breed had worse feed conversion (3.19 $\mathrm{g}$ feed / $\mathrm{g}$ eggs in the system with outdoor access and $3.49 \mathrm{~g}$ feed $/ \mathrm{g}$ eggs in the floor rearing system) as compared to the hybrid used in this experiment $(2.13$ $\mathrm{g}$ feed / $\mathrm{g}$ eggs in the floor system, and $2.40 \mathrm{~g}$ feed $/ \mathrm{g}$ eggs in the rearing system with outdoor access).

Table 2 - Effect of rearing systems and genotypes on the production performance of laying hens.

\begin{tabular}{lcccc}
\hline Rearing system & \multicolumn{2}{c}{ Floor } & \multicolumn{2}{c}{ Organic } \\
\hline Genotype & Isa Brown & New Hampshire & Isa Brown & New Hampshire \\
\hline Egg production (\%) & $75.91^{\mathrm{a}}$ & $40.56^{\mathrm{c}}$ & $77.88^{\mathrm{a}}$ & $55.98^{\mathrm{b}}$ \\
Egg mass $\left(\mathrm{g}\right.$ egg hen day $\left.{ }^{-1}\right)$ & $47.98^{\mathrm{a}}$ & $24.98^{\mathrm{c}}$ & $47.57^{\mathrm{a}}$ & $35.32^{\mathrm{b}}$ \\
Feed consumption $\left(\mathrm{g} \mathrm{day}^{-1}\right)$ & $125.46^{\mathrm{b}}$ & $124.33^{\mathrm{b}}$ & $125.54^{\mathrm{b}}$ & $129.43^{\mathrm{a}}$ \\
Feed conversion (g feed per g egg) & $2.92^{\mathrm{a}}$ & $6.93^{\mathrm{c}}$ & $3.03^{\mathrm{a}}$ & $5.55^{\mathrm{b}}$ \\
\hline
\end{tabular}

$a-c$ : Values within rows with different superscripts are significantly different $(p \leq 0.05)$

However, the data in Table 2 suggest that there was a significant interaction between the rearing systems and genotypes for all production parameters studied. Namely, there was no significant difference in egg production, daily egg mass, and feed conversion between Isa Brown layers in the organic system and those in the floor rearing system $(p \geq 0.05)$. Similar results were reported by Turker \& Alkan (2018), who did not find a significant difference in egg production, feed consumption, and feed conversion between deep-litter and free range Lohman Brown hens; as well as by Ferrante et al. (2009), who analyzed egg production differences between barn and organic HyLine Brown layers. In contrast, New Hampshire hens in the organic system achieved significantly higher egg production and egg mass, as well as better feed conversion $(p \leq 0.05)$ than those reared on the floor, and significantly lower values $(p \leq 0.05)$ when compared to both Isa Brown experimental groups. These results suggest that some genotypes respond better to fresh air and freedom of movement, showing better production performance in a rearing system with outdoor access than in an indoor system. Kucukyilmaz et al. (2012) confirmed that hen genotypes significantly differed in their response to different management procedures. Namely, in their research, White Lohmann LSL layers had a higher egg production rate and higher daily egg mass in the cage system $(89.8 \% ; 59.01 \mathrm{~g})$ than in the organic system $(87.2 \% ; 57 \mathrm{~g})$, while at the same time ATAK-S hens showed lower values of egg production rate and egg mass production in the cage $(80.4 \% ; 50.99 \mathrm{~g})$ when compared with the organic production system $(82.5 \% ; 53.35 \mathrm{~g})$ (all four groups significantly differed, $p \leq 0.05)$. Also, feed conversion rate was significantly affected by the interaction of investigated factors - cage White Lohmann LSL layers $(1.87 \mathrm{~g}$ feed / g eggs), organic ( $2.65 \mathrm{~g}$ feed $/ \mathrm{g}$ eggs), cage ATAK-S $(2.32 \mathrm{~g}$ feed $/ \mathrm{g}$ eggs) and organic ATAK-S (2.43 g feed / g eggs).

Organic New Hampshire hens had significantly higher $(p \leq 0.05)$ average daily feed consumption when compared with the other three experimental groups, which did not vary significantly from each other $(p \geq 0.05)$. The reason why floor-reared New Hampshire hens had significantly lower feed consumption when compared with organic hens lies in their significantly lower productive needs because of much lower egg production. In contrast, organic Isa Brown hens had higher energy requirements than floor reared layers due to higher locomotor activity, which they compensated through outdoor food; therefore, there was no difference between the two Isa Brown groups in terms of feed consumption $(p \geq 0.05)$. This is in agreement with the results published by Henry (2002), who reported that hens raised outdoors can satisfy even $20 \%$ of their food needs by consuming grass, insects and various invertebrates. Mugnai et al. (2013) found no significant difference in feed consumption between caged (109.8 g) and organic (110.4 g) Ancona laying hens.

The mortality of laying hens is presented in Table 3. 
Table 3 - Effect of rearing system and genotype on the mortality of laying hens.

\begin{tabular}{lcccc}
\hline Rearing system & \multicolumn{3}{c}{ Organic } \\
\hline Genotype & Isa Brown & Now Hampshire & Isa Brown & New Hampshire \\
Mortality (\%) & $6 \%$ & $0 \%$ & $6 \%$ & $3 \%$ \\
\hline
\end{tabular}

The effect of the rearing system on the mortality of laying hens was determined by a large number of authors (Mugnai et al., 2009; Gerzilov et al., 2012), but there is also an interaction between rearing system and genotype when considering this parameter (The Humane Society of the United States, 2010). A significant effect of genotype on the mortality of laying hens was also found by Sørensen (2001), who determined different mortality rates for four genotypes in the free-range rearing system - 19.9\% for Isa Brown hens, 13.8\% for New Hampshire, 6.7\% for White Leghorn, and 3.9\% for New Hampshire $x$ White Leghorn.

Egg quality parameters are presented in Table 4.

Organic Isa Brown hens had a significantly lower $(p \leq 0.05)$ egg weight compared with all other experimental groups, which did not differ significantly from each other $(p \geq 0.05)$.

The main reason for these results was the lower level of methionine and cystine in organic feed $(0.48 \%)$ as compared to conventional feed (0.68\%). A similar conclusion was reached by Koreleski \& Świątkiewicz (2009) and Rakonjac et al. (2018a), that is, a limited level of methionine in the feed for organic laying hens may, inter alia, reduce average egg weight. The main reason why organic New Hampshire hens did not respond by decreasing their egg weight was probably their lower egg production rate, which causes reduced levels of methionine in their feed to be sufficient to meet their production needs.

Rearing systems did not cause differences in the egg shape index, which is in agreement with the findings reported by Ahammed et al. (2014), Dikmen et al. (2017), Sokołowicz et al. (2018b, 2019), Rakonjac et al. (2018a, 2018b), and Popova et al. (2020). Isa Brown hens produced rounder eggs than New Hampshire $(p \leq 0.01)$. Škrbić et al. (2011) also found that native breeds produced "pointier" eggs as compared to hybrid hens. A significant effect of genotype on the egg shape index was also determined by Zita et al. (2009), Ledvinka et al. (2012), and Kraus \& Zita (2019).

Rearing systems had no significant effect on the proportions of the main components of the egg $(p \geq 0.05)$, but the rearing system $x$ genotype interaction significantly affected the proportions of albumen and shell $(p \leq 0.01)$. Generally, New Hampshire eggs had a higher content of yolk and a smaller content of albumen when compared with Isa Brown eggs ( $p \leq 0.05)$, which is in agreement with the results published by Rakonjac et al. (2017), who found $2.78 \%$ more yolk and $2.23 \%$ less albumen in New Hampshire than in Isa Brown eggs. Suk \& Park (2001) also confirmed that eggs from native breeds have a higher content of yolk and a smaller content of albumen when compared with eggs from hybrid hens - they found $6.07 \%$ more yolk and $5.38 \%$ less albumen in KNC, Korean native breeds, as compared to the Isa Brown hybrid. There was no significant difference in shell proportion between the examined genotypes in the floor rearing system $(p \geq 0.05)$, while Isa Brown eggs had a significantly higher proportion of the shell compared with New Hampshire eggs $(p \leq 0.01)$ in the organic system. Similar results were reported by Kucukyilmaz et al. (2012), who found a significantly higher $(p \leq 0.05)$ proportion of

Table 4 - Effect of rearing system and genotype of laying hens on egg quality.

\begin{tabular}{|c|c|c|c|c|c|c|c|c|}
\hline Rearing system (RS) & & loor & & ganic & ANOVA & RS & $\mathrm{G}$ & $\mathrm{RS} \times \mathrm{G}$ \\
\hline Genotype (G) & Isa Brown & New Hampshire & Isa Brown & New Hampshire & & & & \\
\hline Egg weight (g) & $69.43^{\mathrm{a}}$ & $69.67^{a}$ & $63.92^{\mathrm{b}}$ & $68.67^{a}$ & & $\star$ & $*$ & * \\
\hline Egg shape index & $76.60^{a}$ & $74.47^{b}$ & $76.20^{a}$ & $73.80^{b}$ & & NS & ** & NS \\
\hline Albumen proportion (\%) & $60.27^{a}$ & $56.14^{c}$ & $58.86^{\mathrm{ab}}$ & $58.42^{b}$ & & NS & ** & ** \\
\hline Yolk proportion (\%) & $27.30^{c}$ & $31.45^{\mathrm{a}}$ & $27.67^{c}$ & $29.87^{b}$ & & NS & ** & NS \\
\hline Shell proportion (\%) & $12.43^{b}$ & $12.41^{b}$ & $13.47^{\mathrm{a}}$ & $11.71^{c}$ & & NS & ** & ** \\
\hline Albumen height (mm) & $5.93^{b}$ & $7.69^{a}$ & $6.65^{b}$ & $6.80^{\mathrm{ab}}$ & & NS & ** & * \\
\hline Haugh unit & $70.93^{b}$ & $84.40^{\mathrm{a}}$ & $78.60^{a}$ & $78.80^{a}$ & & NS & ** & * \\
\hline Shell thickness (mm) & $0.330^{\mathrm{a}}$ & $0.303^{b}$ & $0.333^{\mathrm{a}}$ & $0.280^{c}$ & & NS & ** & * \\
\hline Shell deformation $(\mu \mathrm{m})$ & $21.53^{b}$ & $25.73^{\mathrm{a}}$ & $20.47^{b}$ & $28.20^{a}$ & & NS & ** & NS \\
\hline Shell strength $(\mathrm{N})$ & $38.26^{a}$ & $39.58^{a}$ & $42.38^{a}$ & $32.72^{b}$ & & NS & * & ** \\
\hline
\end{tabular}

a-c: Values within rows with different superscripts are significantly different $(p \leq 0.05)$

${ }^{*}-p \leq 0.05,{ }^{* *}-p \leq 0.01, \mathrm{NS}-$ non-significant 
the shell in Lohmann LSL organic eggs (10.58\%) than in cage eggs of the same genotype (10.36\%), while there was no significant difference in shell proportion between organic and cage ATAK-S eggs (9.77\%: $9.63 \%, p \geq 0.05)$. A significant effect of the rearing system $x$ genotype interaction on shell proportion was determined by Svobodova et al. (2014).

The eggs of New Hampshire breeds in the floor rearing system had a significantly higher albumen height and Haugh units as compared to the organic eggs of this genotype $(p \leq 0.05)$, while no differences were recorded for the Isa Brown hybrid $(p \geq 0.05)$. Kucukyilmaz et al. (2012) also established a significant effect of the rearing system $x$ genotype interaction on albumen height and Haugh units in the eggs. Namely, Lohmann LSL conventional system hybrid eggs $(6.90 \mathrm{~mm} ; 82.13)$ and those from the organic production system $(7.01 \mathrm{~mm} ; 81.15)$ showed no significant differences in albumen height and Haugh units ( $p \geq 0.05)$. Conversely, ATAK-S hybrids's eggs from the organic system $(6.35 \mathrm{~mm} ; 77.73)$ had significantly higher $(p \leq 0.05)$ values of the investigated parameters than eggs of this genotype reared in the floor rearing system $(6.10 \mathrm{~mm} ; 75.50)$. A significant effect of the rearing system $x$ genotype interaction on albumen height and Haugh units was also found by Sokołowicz et al. (2018a, 2018b).

Isa Brown hens generally had better eggshell quality as compared to New Hampshire hens, but the genotype $x$ rearing system interaction had a strong effect on two of the three eggshell quality traits examined. New Hampshire hens from the floor rearing system had significantly higher $(p \leq 0.05)$ eggshell thickness when compared with organic hens of the same genotype, while the experimental Isa Brown groups were not different from each other $(p \geq 0.05)$, but had a significantly higher $(p \leq 0.01)$ value of this parameter when compared with the New Hampshire genotype. Mostert et al. (1995) also found significantly lower $(p \leq 0.05)$ eggshell thickness in the New Hampshire breed $(0.311 \mathrm{~mm})$ when compared with eggs from three commercial hybrids $(0.332 \mathrm{~mm}, 0.329 \mathrm{~mm}$ and
$0.333 \mathrm{~mm}$ ) reared in cage, floor and free-range systems, respectively. A significant effect of the rearing system $x$ genotype interaction on eggshell thickness was also observed by Ledvinka et al. (2012) in Isa Brown, Hisex Brown and Moravia BSL genotypes, in the floor and cage production systems, as well as by Sokołowicz et al. (2018a) in Green-legged Partridge, Rhode Island Red, and Hy-Line Brown in litter barn, free-range, and organic rearing systems. New Hampshire layers had higher eggshell deformation when compared with Isa Brown hybrid's $(p \leq 0.01)$. Svobodova et al. (2014) also determined a crucial effect of genotype on this trait: in both systems (cage and floor), both genotypes had identical eggshell deformation - Lohmann white 0.29 $\mathrm{mm}$ and Czech hen $0.31 \mathrm{~mm}$. Organic New Hampshire hens had significantly lower $(p \leq 0.05)$ eggshell strength when compared with all three experimental groups, which did not differ significantly from each other $(p \geq 0.05)$. These results can be explained by the interaction of numerous factors affecting eggshell quality, including genotype, hen age, mating, nutrition, stress, some diseases, climatic factors, and rearing system (Roberts, 2004), and in the present study they probably caused reduced eggshell quality in organic New Hampshire hens. A significant effect of the rearing system $x$ genotype interaction on shell thickness and shell strenght was also determined by Sokołowicz et al. (2018b).

Table 5 showed that there was no significant effect of the rearing system on these traits, which is in agreement with the results published by Minelli et al. (2007), Nistor et al. (2014) and Kiczorowska et al. (2015). New Hampshire eggs had a higher dry matter $(p \leq 0.01)$ and minerals $(p \leq 0.01)$ content when compared with Isa Brown eggs. Similarly, Pavlovski et al. (2011) determined higher dry matter (25.59\%) and minerals $(0.93 \%$ ) contents in breed eggs (Naked Neck) when compared with hybrid (Hy-Line) hens (23.04\% and $0.88 \%$, respectively).

Rearing systems had no significant effect on the protein content of eggs ( $p \geq 0.05)$, which is consistent with the findings published by Krawczyk \& Gornowicz

Table 5 - Effect of laying hens' rearing systems and genitypes on the chemical composition of eggs.

\begin{tabular}{|c|c|c|c|c|c|c|c|c|}
\hline Rearing system (RS) & & or & & yanic & ANOVA & RS & G & $\mathrm{RS} \times \mathrm{G}$ \\
\hline Genotype (G) & Isa Brown & New Hampshire & Isa Brown & New Hampshire & & & & \\
\hline Dry matter (\%) & $23.65^{c}$ & $25.42^{a}$ & $24.16^{\mathrm{bc}}$ & $25.13^{a b}$ & & NS & $* *$ & NS \\
\hline Minerals (\%) & $0.89^{a b}$ & $0.93^{a}$ & $0.87^{b}$ & $0.91^{\mathrm{ab}}$ & & NS & * & NS \\
\hline Protein (\%) & $12.14^{b}$ & $12.71^{\mathrm{a}}$ & $12.38^{a b}$ & $12.14^{b}$ & & NS & NS & $\star *$ \\
\hline Lipids (\%) & $9.29^{b}$ & $10.33^{a}$ & $9.13^{b}$ & $10.29^{a}$ & & NS & ** & NS \\
\hline
\end{tabular}

$a-c$ : Values within rows with different superscripts are significantly different $(p \leq 0.05)$

${ }^{*}-p \leq 0.05,{ }^{*}$ * $-p \leq 0.01$, NS - non-significant 
(2010) and Radu-Rusu et al. (2014). Also, Rakonjac et al. (2018b) found no difference in the protein content between floor and organic eggs. However, there was a strong interaction between the examined factors $(p \leq 0.01)$, and therefore floor-reared New Hampshire hens had a significantly higher egg protein content as compared to organic New Hampshire and floor-reared Isa Brown layers (which had identical egg protein contents). Organic Isa Brown hens had an intermediate value of this parameter and did not differ from any of the other three experimental groups $(p \geq 0.05)$. Similarly to our results, Kucukyilmaz et al. (2012) observed no significant difference in the protein content of eggs between organic and caged ATAK-S hens (both groups at $13.32 \%)$. However, in the same experiment, organic Lohmann LSL layers displayed a higher $(p \leq 0.05)$ protein content $(13.19 \%)$ as compared to caged hens of the same genotype $(12.85 \%)$, which showed that some genotypes can respond differently in rearing systems with outdoor access and thus cause differences in eggs' protein content. A significant effect of the rearing system on protein content in eggs was also determined by Perić et al. (2016) and Yenice et al. (2016).

There was no significant effect of the rearing systems on the lipid content of eggs, which is in agreement with the findings published by Rakonjac et al. (2018b), who found no difference in the lipid content between floor and organic eggs, while cage eggs had a higher lipid content when compared with the previous two groups. The absence of a significant effect of rearing system on this characteristic was also determined by Minnelli et al. (2007), Krawczyk \& Gornowicz (2010), Pavlovski et al. (2011) and Filipiak-Florkiewicz et al. (2017).

New Hampshire hens had a significantly higher lipid content in eggs $(p \leq 0.01)$ when compared to Isa Brown. The significantly higher content $(p \leq 0.01)$ of lipids in the yolk of the breed (Araucana - 27\%) compared with the hybrid (Isa Brown - 20\%) was also established by Pintea et al. (2012).

\section{CONCLUSION}

Generally, Isa Brown hens had better production performance when compared with the New Hampshire breed. At the same time, organic New Hampshire layers were dominant when compared with floorreared ones.

Genotype had a significant effect on all ten egg quality parameters (external, internal and eggshell quality), while rearing system independently affected only egg weight. However, the interaction of the observed factors significantly influenced seven tested parameters. Genotype similarly had a significant effect on three of the four chemical composition parameters of chemical composition, while there was no significant effect of the rearing system on the chemical composition of eggs. The rearing system $x$ genotype interaction significantly influenced the protein content of eggs.

These results indicate that in alternative rearing systems, especially organic ones, special attention must be given to the choice of genotype, because most of the examined properties were significantly affected by the breeding system $x$ genotype interaction.

\section{ACKNOWLEDGEMENTS}

This work was supported by the Ministry of Education, Science and Technological Development of the Republic of Serbia, Contracts No. 451-03-68/202014/200088 and 451-03-68/2020-14/200022.

\section{REFERENCES}

Abeyrathne EDNS, Lee HY, Ahn DU. Egg white proteins and their potential use in food processing or as nutraceutical and pharmaceutical agents a review. Poultry Science 2013;92:3292-3299.

Ahammed M, Chae BJ, Lohakare J, Keohavong B, Lee MH, Lee SJ, et al. Comparison of aviary, barn and conventional cage raising of chickens on laying performance and egg quality. Asian-Australasian Journal of Animal Science 2014;27(8):1196-1203.

AOAC - Association of Official Analytical Chemists. Official methods of analysis. $13^{\text {th }}$ ed. Arlington; 1990. $1018 \mathrm{p}$.

Committee for the Common Organisation of the Agricultural Markets. EU market situation for eggs. Brussels; 2021

Dikmen BY, Ipek A, Şahan Ü, Sözcü A, Baycan SC. Impact of different housing systems and age of layers on egg quality characteristics. Turkish Journal of Veterinary and Animal Science 2017;41:77-84.

Ferrante V, Lolli S, Vezzoli G, Cavalchini LG. Effects of two different rearing systems (organic and barn) on production performance. animal welfare traits and egg quality characteristics in laying hens. Italian Journal of Animal Science 2009;8:165-174.

Filipiak-Florkiewicz A, Deren K, Florkiewicz A, Topolska K, Juszczak L, Cieslik E. The quality of eggs (organic and nutraceutical vs. conventional) and their technological properties. Poultry Science 2017;96:2480-2490.

Gerzilov V, Datkova V, Mihaylova S, Bozakova N. Effect of poultry housing system on egg production. Bulgarian Journal of Agricultural Science 2012;18(6):953-957.

Henry R. Organic poultry: eggs. Maritime Certified Organic growers Organic profiles; 2002. Disponível em: https://www.acornorganic.org/ media/resources/poultryeggsprofile.pdf

Kiczorowska B, Samolińska W, Kwiecień M, Winiarska-Mieczan A, RusinekPrystupa E, Al-Yasiry ARM. Nutritional value and the content of minerals in eggs produced in large-scale, courtyard and organic systems. Journal of Elementology 2015;20(4):887-895. 
Korelenski J, Światkiewicz S. Laying performance and nitrogen balance in hens fed organic diets with different energy and methionine levels. Journal of Animal and Feed Sciences 2009;18:305-312.

Krawczyk J, Gornowicz E. Quality of eggs from hens kept in two different free-range systems in comparison with a barn system. Archiv für Geflügelkunde 2010;74:151-157.

Kraus A, Zita L. The effect of age and genotype on quality of eggs in brown egg-laying hybrids. Acta Universitatis Agriculturae et Silviculturae Mendelianae Brunensis 2019;67(2):407-414.

Kucukyilmaz K, Bozkurt M, Herken EN, Cinar M, Cath AU, Bintas E, et al. Effects of rearing systems on performance, egg characteristics and immune response in two layer hen genotype. Asian-Australan Journal of Animal Sciences 2012;25(4):559-568.

Ledvinka Z, Tůmová E, Englmaierová M., Podsedníček M. Egg quality of three laying hen genotypes kept in conventional cages and on litter. Archiv für Geflügelkunde 2012;76(1):38-43.

Minelli G, Sirri E, Folegatti A, Melluzzi A, Franchini A. Egg quality traits of laying hens reared in organic and conventional systems. Italian Journal of Animal Science 2007;6 Suppl. 1:728-730.

Molnár S, Szollosi L. Sustainability and quality aspects of different table egg production systems: a literature review. Sustainability 2020;12:7884.

Mostert BE, Bowens EH, Van den Valt JC. Influence of different housing systems on the performance of hens of four laying strains. South African Journal of Animal Science 1995;25(3):80-86.

Mugnai C, Dal Bosco A, Castellini C. Effect of rearing system and season on the performance and egg characteristics of Ancona laying hens. Italian Journal of Animal Science 2009;88:175-188.

Mugnai C, Sossidou EN, Dal Bosco A, Ruggeri S, Mattioli S, Castellini C. The effects of husbandry system on the grass intake and egg nutritive characteristics of laying hens. Journal of the Science and Food and Agriculture 2013;94(3):459-467.

Nistor Cotfas LI, Albu A, Usturoi MG. Knowledge of chemical indicators of eggs from hens reared in conventional and free range system. Bulletin UASVM Food Science and Technology 2014;71(2):119-124.

Pavlovski Z, Vitorović D. Direktan metod za određivanje čvrstoće ljuske jaja. Nauka u Živinarstvu 1996;3-4:171-175.

Pavlovski Z, Škrbić Z, Lukić M, Lilić S, Krnjaja V, Staničić N, et al. Comparative analysis of fatty acid profile and cholesterol content in table eggs from different genotype hens. Biotechnology in Animal Husbandry 2011;27(3):669-677.

Perić L, Đukić-Stojčić M, Bjedov S. Effect of production systems on quality and chemical composition of table eggs. Contemporary Agriculture 2016;65(3-4):27-31.

Pintea A, Dulf FV, Bunea A, Matea C, Andrei S. Comparative analysis of lipophilic compounds in eggs of organically raised ISA Brown and Araucana hens. Chemical Papers 2012;66(10):955-963.

Popova T, Petkov E, Ayasan T, Ignatova M. Quality of eggs from layers reared under alternative and conventional system. Brazilian Journal of Poultry Science 2020;22(1):1-8.

Radu-Rusu RM, Ustroi MG, Leahu A, Amariei S, Radu-Rusu CG, VacaruOpris I. Chemical features. cholesterol and energy content of table hen eggs from conventional and alternative farming systems. South African Journal of Animal Science 2014;44(1):33-42.

Rakonjac S, Bogosavljević-Bošković S, Škrbić Z, Perić L, Dosković V, Petrović MD, et al. The effect of the rearing system. genotype and laying hens age on the egg weight and share of main parts of eggs. Acta Agriculturae Serbica 2017;22(44):185-192.
Rakonjac S, Petrović MD, Bogosavljević-Bošković S, Škrbić Z, Perić L, Dosković $\mathrm{V}$, et al. Effect of age and season on production performance and egg quality of laying hens from different rearing systems. The Journal of Animal and Plant Science 2018a;28(6):1602-1608.

Rakonjac S, Bogosavljević-Bošković S, Škrbić Z, Lukić M, Dosković V, Petričević $V$, et al. Quality and chemical composition of eggs affected by rearing system and hen's age. Biotechnology in Animal Husbandry 2018b;34(3):343-352.

Rakonjac S, Bogosavljević-Bošković S, Škrbić Z, Lukić M, Dosković V Petrović MD, et al. Egg charesteristics of New Hampshire laying hens from floor and organic rearing systems. Acta Agriculturae Serbica 2019;24(48):87-95

Rizzi C, Chiericato GM. Organic farming production. Effect of age on the productive yield and egg quality of hens of two commercial hybrid lines and two local breeds. Italian Journal of Animal Science 2005;4 Suppl 3:160-162.

Roberts JR. Factors affecting egg internal quality and egg shell quality of laying hens. Journal of Poultry Science 2004;41:161-177.

Siró I, Kápolna E, Kápolna B, Lugasi A. Functional food. Product development, marketing and consumer acceptance - A review. Appetite 2008; 51:456-467.

Sokołowicz Z, Krawczyk J, Dykiel M. Effect of alternative housing system and hen genotype on egg quality characteristics. Emirates Journal of Food and Agriculture 2018a;30(8):695-703.

Sokołowicz Z, Krawczyk J, Dykiel M. The effect of the type of alternative housing system, genotype and age of laying hens on egg quality. Annals of Animal Science 2018b;18(2):541-555.

Sokołowicz Z, Krawczyk J, Dykiel M, Augustyńska-Prejsnar A. Effect of layer genotype on physical characteristics and nutritive value of organic eggs. CyTA - Journal of Food 2019;17(1):11-19.

Sørensen P. Breeding strategies in poultry for genetic adaptation to the organic environment. In: Hovi M, Baars T, editors. Breeding and feeding for animal health and welfare in organic livestock systems. Wageningen: Network for Animal Health and Welfare in Organic Agriculture; 2001. p.51-61.

Stat Soft Inc Statistica For Windows. Version 7.0. Computer program manual. Tulsa; 2006.

Svobodova J, Tůmova E, Englmaierova M. The effect of housing system on egg quality of Lohmann white and Czech hen. Acta fytotechnica zootechnica 2014;17(2):44-46.

Suk YO, Park C. Effect of Breed and Age of Hens on the Yolk to Albumen Ratio in Two Different Genetic Stocks. Poultry Science 2001;80:855858.

Škrbić Z, Pavlovski Z, Lukić M, Vitorović D, Petričević V, Stojanović L. Changes of egg quality properties with the age of layer hens in traditional and conventional production. Biotechnology in Animal Husbandry 2011;27(3):659-667.

Turker I, Alkan S. Comparison of hens reared in free-range and deeplitter systems in terms of certain production characteristics. Journal of Agricultural Sciences 2018;24:179-184.

The Humane Society of the United States. Understanding mortality rates of laying hens in cage-free egg production systems [paper 3]. Washington; 2010. Available from: https://www.humanesociety.org/sites/default/ files/docs/mortality-cage-free-egg-production-system.pdf.

Yenice G, Kaynar O, lleriturk M, Hira F, Hayirli A. Quality of eggs in different production systems. Czech Journal of Food Science 2016;34(4):370376 .

Zita L, Tumova E, Štolc L. Effects of genotype, age and their interaction on egg quality in brown-egg laying hens. Acta Veterinaria Brno 2009;78:85-91. 
